\title{
FACTORS THAT INFLUENCE THE TIMELINESS OF PUBLICATION OFFINANCIAL STATEMENTS ON BANKING IN INDONESIA
}

\author{
Galuh Hesti Wulandari \\ ${ }^{1)}$ Accounting, UniversitasTeknokrat Indonesia \\ Jl. ZainalAbidin Pagaralam, No 9-11, Labuhanratu,Bandarlampung \\ Email : galuhhestii@gmail.com
}

\begin{abstract}
The purpose of this study is to examine the effect of financial ratios, firm age, firm size, and auditor's opinion on the timeliness of publication of banking financial statements listed on the Indonesia Stock Exchange (IDX). The population in this study were 87 banking companies during the period 2010-2012. The number of sample companies in this study is 29 companies. Samples were taken based on purposive sampling method. Data were analyzed using logistic regression technique.

The results showed that the variable financial ratios have a significant positive effect on the timeliness of the publication of financial statements. The variable of firm size has significant influence, but has negative direction to the timeliness of publication of financial report, while the variable of firm age and auditor's opinion does not affect the timeliness of publication of financial report.
\end{abstract}

Keywords: Timeliness, Profitability, Liquidity, Solvency, Firm Age, Firm Size, Auditor’s Opinion.

\section{Introduction}

Timeliness of the publication of financial statements is an important characteristic of financial statements.In the Statement of Financial Accounting Concept (SFAC) number 2 which describes the qualitative characteristics of financial information, timeliness is one of the qualitative characteristics that supports the achievement of relevant qualities other than predictive value and feedback value.

The quality of relevant information itself is very closely related to decision making.Therefore, it is important for management not to postpone the presentation and publication of its financial statements so that the information does not lose its ability to influence decision making, so that management really needs to consider what factors can influence the timeliness of the publication of financial statements. This study examines the factors that are thought to influence the timeliness of the publication of financial statements.

\section{Discussion}

Research conducted by I GustiAyu Maharani (2013) shows that firm size, profitability, leverage ratio, extraordinary and / or contingencyitems, and firm age has no significant effect on the timeliness of financial reporting publication. While research conducted by Hilmi and Ali (2008) states that liquidity affects the timeliness of financial statement submission but otherwise the opinion of the auditor has no effect.

Profitability is the company's ability to make a profit. It can be said that the income is a good news for a company. Liquidity is defined as the ability of a company to pay off current debt by using the company's current assets. High liquidity indicates that the company has a high ability to pay off its short-term obligations.

Solvency is the company's ability to pay all its debts from the company's assets. Made Gede (2004) explains that companies with a high solvency ratio will tend to have a longer timeframe for the presentation and publication of financial statements. The firm age is the length of life of a company that shows the existence of a company. Owusu and Ansah (2000) stated that older companies tend to be more skilled at producing information.

Company size is a scale that shows the size and size of a company. The larger the size of the company will attract investors to determine their investment decisions. The main objective of the audit on financial statements is to express an opinion whether the client's financial statements are presented fairly, in all material respects, in accordance with GAAP (Mulyadi, 2002). Companies that get an unqualified opinion, are good news from the auditor for their financial statements so that they will be faster in publishing financial statements. 


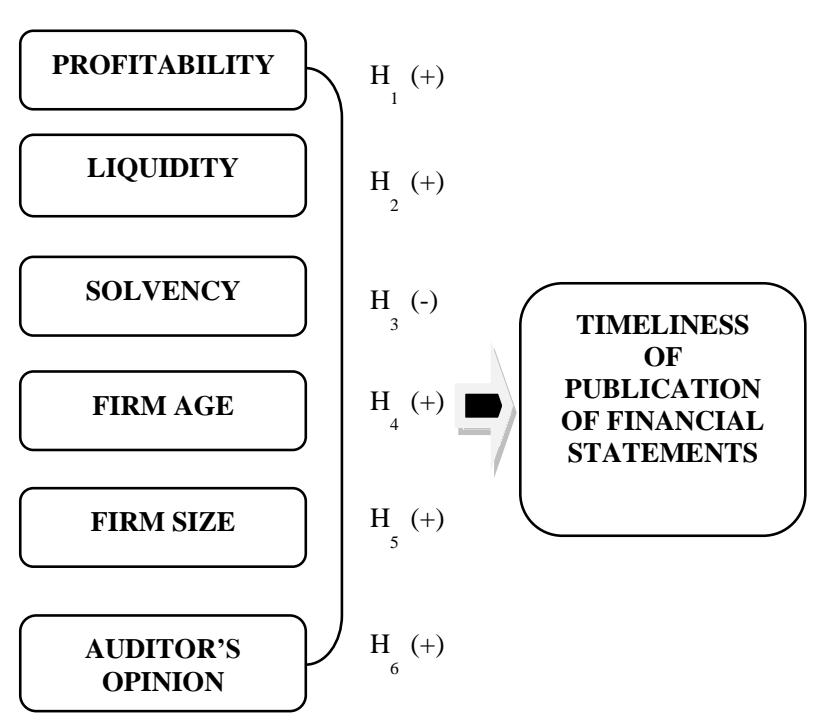

Picture 1.Research Model

The analysis of independent variable influence on variables dependent using the logisitic regression model.

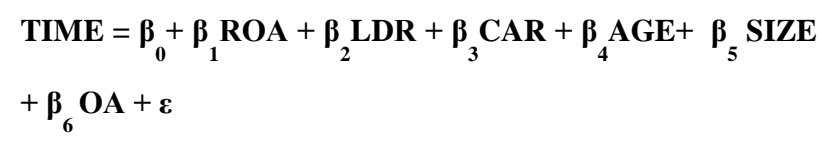

Based on Table 1, with a significance level of $0.05(5 \%)$, its obtained logistic regression equation as follows:

TIME $=7,157+6,374$ ROA + 0,372 LDR +1,0111
CAR + 0,163 AGE -6,436 Asset + 28,409 OA + +

The dependent variable is measured using a dummy variable category: Companies are not timely (late) entry category 0 and timely company in the category 1 . While the independent variable is measured as follows:

2.1 Profitability in this study is measured by the ratio of Return on Assets (ROA).

$$
R O A=\frac{\text { Income before Tax }}{\text { Mean of Total Asset }}
$$

2.2 Liquidity is measured by the formula Loan to Deposit Ratio. Liquidity can be measured by using the formula:

$$
L D R=\frac{\text { Credit }}{\text { Third Parties Fund }} \times 100 \%
$$

2.3The solvency ratio in this study will be measured using Capital Adequancy Ratio, based on SE Bank Indonesia No. 13/30/DPNP/2011:

$$
C A R=\frac{\text { Equity }}{\text { Aset Tertimbang Menurut Risiko }}
$$

2.4Firm age in this study is measured by the formula:

Firm Age $=$ years listed on the IDX until the year of research

2.5 Firm size is measured by using property owned by a company (the log of Total Assets):

$$
\text { Size }=\text { Log of Total Assets }
$$

2.6 Auditor'sopinion in this study is measured using dummy variables. The company that received an unqualified opinion was given a value of 1 and the company that received an opinion other than the unqualified opinion was given a value of 0 .

The testing of hypotheses by using regression logistics served in table 1 .

Table 1. Results of Logistic Regression

\begin{tabular}{|c|c|c|c|c|c|}
\hline $\begin{array}{c}\text { Variabel } \\
\text { Independent }\end{array}$ & B & S.E. & Wald & Sig. & Result \\
\hline ROA & 6.374 & 2.700 & 5.574 & 0.018 & Significant \\
\hline LDR & 0.372 & 0.157 & 5.595 & 0.018 & Significant \\
\hline CAR & 1.011 & 0.495 & 4.179 & 0.041 & Significant \\
\hline AGE & 0.163 & 0.130 & 1.568 & 0.210 & $\begin{array}{c}\text { Not } \\
\text { Significant }\end{array}$ \\
\hline ASSET & -6.436 & 2.944 & 4.781 & 0.029 & Significant \\
\hline OA & 28.409 & 21121.536 & 0.000 & 0.999 & $\begin{array}{c}\text { Not } \\
\text { Significant }\end{array}$ \\
\hline
\end{tabular}

Source: Secondary data processed, 2014

Profitability (ROA) in companies that are on time have an average of $2.2729 \%$ higher than companies that are not on time with an average of $-0.3414 \%$. Liquidity (LDR) shows that companies that are not on time have lower ratios compared to companies that are on time with an average ratio of $69.0214 \%$ and $79.5360 \%$. Solvency (CAR) shows a comparison of mean on companies that are not on time with companies that are timely at $15.18 \%$ and $16.8185 \%$. Firm age at the timely company has an average age of 11.75 years and that is not timely at 13.28 years. Company size (Log_TA) in companies that publish in a timely manner is 13,4783 and for companies that are not on time, that is equal to 13,2765 , while for auditor opinion (OA) on companies that are not on time have an average of 0,7857 and a timely company of 1,000 .

The feasibility of the regression model (Goodness of Fit) is shown from the results of the Hosmer and Lemeshow Test with a probability level $>0.05$ and Overall Model Fit by looking at $-2 \log$ likelihood which shows a decrease 
in the value of $-2 \log$ likelihood by $76.767-59.581=$ 17.186 which has a level significance of $0.400>0.05$. These results indicate that the regression model is good and feasible to be used in this study.

The results of this study indicate that companies that obtain high profits tend to be timely in publishing their financial statements and vice versa if they experience losses.

Testing on the Liquidity variable (LDR) has a regression coefficient of 0.372 and a probability of 0.018 whose value is below 0.05 . These results are consistent with research conducted by Hilmi and Ali (2008) who found that liquidity has a significant influence on the timeliness of the publication of financial statements. This shows the good news, that companies that have a high level of liquidity have a high ability to pay off short-term obligations so that companies with these conditions tend to be timely in the publication of their financial statements.

Testing on the Solvency variable (CAR) has a regression coefficient of 1.011 and a probability of 0.041 whose value is below 0.05 . This means that there is a significant positive effect on the company's solvency on the timeliness of the publication of financial statements, so the third hypothesis cannot be supported, because it has a positive direction that is contrary to the hypothesis.

Testingonfirmage variables (AGE) has a regressioncoefficient of 0.163 and a probability of 0.210 whosevalueisabove 0.05 ( $p>0.05)$. Thismeansthatthereis no significantinfluence of thefirm ageonthetimeliness of thepublication of financialstatements.

Testing on company size variables (SIZE) has a regression coefficient of -6.436 and a probability of 0.029 whose value is above 0.05 . This means that there is a significant negative influence on the size of the company on the timeliness of the publication of financial statements, however the fifth hypothesis is rejected.

Testing on the auditor opinion variable is known that the regression coefficient value is 28.409 and the probability is 0.999 whose value is above 0.05 . Thus there is no significant effect on auditor opinion on the timeliness of the publication of financial statements.

\section{Conclusion}

The results of the study show that there are positive and significant effects between the variables of profitability, liquidity, and solvency on the timeliness of the publication of financial statements. Then the firm size variable was also found to have a significant negative relationship to the timeliness of the publication of financial statements, as well as firm age and auditor's opinions variables that had no significant relationship to the timeliness of the publication of financial statements.

Investors should choose companies that are profitable, liquid, solvable, and have small assets, because companies that have such characteristics will tend to communicate and publish the annual financial statement faster.

This research is only limited to banking companies, so the research results cannot see the trends that occur in the long term and do not represent all categories of companies listed on the Indonesia Stock Exchange.

\section{References}

IkatanAkuntansi Indonesia. 2007. Standar Akuntansi Keuangan. Jakarta: Salemba Empat.

Maharani, I Gusti Ayu. 2013. "Ketepat waktuan Penyampaian Pelaporan Keuangan Dan FaktorFaktor Yang Mempengaruhi Pada Perusahaan Perbankan”. E-Jurnal Akuntansi Universitas Udayana. Vol.2, No. 2, Februari 2013. pp.402415.

Mulyadi. 2002. Auditing. Edisi Pertama. Cetakan Keenam. Salemba Empat.Jakarta.

Owusu-Ansah, Stephen. 2000. "Timeliness of Corporate Financial Reporting in Emerging Capital Market: Empirical Evidence from The Zimbabwe Stock Exchange". Journal Accounting and Business Research.Vol.30. No.3.pp.241-254.

Hilmi, Utari, danSyaiful Ali. 2008. "Analisis FaktorFaktor Yang Memepengaruhi Ketepatan Waktu Penyampaian Laporan Keuangan (Studi Empiris pada Perusahaan-perusahaan yang Terdaftar di BEJ)". Simposium Nasional Akuntansi XI Ikatan Akuntan Indonesia.

Wirakusuma, Made Gede. 2004. "Faktor-Faktor Yang Mempengaruhi Rentang Waktu Penyajian Laporan Keuangan ke Publik (Studi Empiris Mengenai Keberadaan Divisi Internal Audit pada Perusahaan-Perusahaan Yang Terdaftar di Bursa Efek Jakarta)". Simposium Nasional Akuntansi VII. (Desember) :pp 1202.1222. 